\title{
SARS-CoV-2 outbreak on the Caribbean islands of the Dutch Kingdom: a unique challenge
}

\author{
Priscilla Maria ${ }^{1}$, Lung Jeung ${ }^{2}$, Ashley Duits ${ }^{3}$ and Jamiu Busari ${ }^{4}$
}

Suggested citation Maria PA, Jeung L, Duits AJ and Busari JO. SARS-CoV-2 outbreak on the Caribbean islands of the Dutch Kingdom: a unique challenge. Rev Panam Salud Publica. 2020;44:e91 https://doi.org/10.26633/RPSP.2020.91

\begin{abstract}
As the severe acute respiratory syndrome coronavirus 2 (SARS-CoV-2) pandemic progresses, countries are depending on one another to acquire knowledge regarding effective measures to contain the virus. Public health measures to suppress transmissions have proven successful in Singapore, Hong Kong and Taiwan. Implementing and adhering to these interventions is challenging, with governments struggling to find a balance between necessary mitigation and suppression strategies, and interruptions of social-economic activities. While large high-income countries are struggling to keep their health systems and economies moving forward, small island developing states are facing even more significant challenges. Many Caribbean islands, including the six islands within the Dutch Kingdom, have been quick to implement stringent public health measures, yet they are facing unique challenges.
\end{abstract}

Keywords $\quad$ Coronavirus; pandemics; West Indies; Caribbean Region; Americas.

As the severe acute respiratory syndrome coronavirus 2 (SARS-CoV-2) pandemic progresses, countries are depending on one another to acquire knowledge regarding effective measures to contain the virus. Public health measures to suppress transmissions have proven successful in Singapore, Hong Kong and Taiwan.(1,2) Implementing and adhering to these interventions is challenging, with governments struggling to find a balance between necessary mitigation and suppression strategies, and interruptions of social-economic activities. While large high-income countries (HIC) are struggling to keep their health systems and economies moving forward, small island developing States (SIDS) are facing even more significant challenges. Many Caribbean islands, including the six islands within the Dutch Kingdom, have been quick to implement stringent public health measures. Nevertheless, with the populations on the islands ranging from only 1,900 to 160,000 , they are facing unique challenges.

\section{THE SITUATION THUS FAR}

As soon as the first local cases of coronavirus disease 2019 (COVID-19) were reported, the governments of the islands were quick to take decisive measures, choosing to close their airspace and implement the necessary mitigation measures.(3) As of now Bonaire has 2 positive cases (308 tested), Saba 3 positive cases (125 tested), and Statia 2 positive cases (17 tested). (4-5) All three pre-emptively closed off their borders, with the first case reported on April $16^{\text {th }}$, April $12^{\text {th }}$ and March $31^{\text {st }}$ respectively. Curaçao, as of now, has 21 confirmed cases (1100 tested, 1 by death) since the first reported case on March $12^{\text {th }}$ with most of these "imported cases" involving people who were visiting or residents who arrived from abroad. In both St. Martin and Aruba, however, at one point the virus was spreading locally within the community with 77 (450 tested, 15 deaths) and 101 cases (2150 tested, 3 deaths) respectively registered since the first reported cases on the $1^{\text {st }}$ and $13^{\text {th }}$ of March 2020.(7-8) (Table 1)

\footnotetext{
1 Amsterdam UMC, Amsterdam, Netherlands $\bowtie$ priscilla.a.maria@gmail.com

2 Radboud UMC, Nijmegen, Netherlands
} 
TABLE 1. Demographics of the six islands (with the Netherlands for reference) and impact of COVID-19 as of June 8

\begin{tabular}{|c|c|c|c|c|c|c|c|}
\hline & Aruba & Bonaire & Curaçao & St. Martin & $\begin{array}{l}\text { Statia (St. } \\
\text { Eustatius) }\end{array}$ & Saba & The Netherlands \\
\hline Population & $\begin{array}{c}112,309 \dagger \\
(10)\end{array}$ & $\begin{array}{l}20,104 \dagger \\
(10)\end{array}$ & $\begin{array}{c}158,665 \dagger \\
(10)\end{array}$ & $\begin{array}{c}41,486 \ddagger \\
(10)\end{array}$ & $\begin{array}{c}3,138 \dagger \\
(10)\end{array}$ & $\begin{array}{c}1,915 \dagger \\
(10)\end{array}$ & $17,424,978(10)$ \\
\hline GDP & $\begin{array}{c}1.862 \text { billion USD } \\
(2017) \\
(10)\end{array}$ & $\begin{array}{c}434 \text { million USD } \\
(2016) \\
(28)\end{array}$ & $\begin{array}{c}2.841 \text { billion USD } \\
(2017) \\
(10)\end{array}$ & $\begin{array}{c}894 \text { million USD } \\
(2017) \\
(10)\end{array}$ & $\begin{array}{c}100 \text { million USD } \\
(20168) \\
(28)\end{array}$ & $\begin{array}{c}48 \text { million USD } \\
(20168) \\
(28)\end{array}$ & $\begin{array}{c}913.658 \text { billion USD } \\
(2018) \\
(10)\end{array}$ \\
\hline $\begin{array}{l}\text { World Bank } \\
\text { Classification }\end{array}$ & High-Income & - & High-Income & High-Income & - & - & High-income \\
\hline Country status & $\begin{array}{l}\text { Autonomous country } \\
\text { within the Dutch } \\
\text { Kingdom (1986) }\end{array}$ & $\begin{array}{c}\text { Special } \\
\text { municipality within } \\
\text { the Netherlands } \\
(2010)\end{array}$ & $\begin{array}{c}\text { Autonomous } \\
\text { country within the } \\
\text { Dutch Kingdom } \\
(2010)^{*}\end{array}$ & $\begin{array}{l}\text { Autonomous } \\
\text { country within the } \\
\text { Dutch Kingdom } \\
(2010)^{*}\end{array}$ & $\begin{array}{c}\text { Special } \\
\text { municipality within } \\
\text { the Netherlands } \\
(2010)\end{array}$ & $\begin{array}{l}\text { Special } \\
\text { municipality within } \\
\text { the Netherlands } \\
(2010)\end{array}$ & $\begin{array}{l}\text { Autonomous country } \\
\text { within the Dutch } \\
\text { Kingdom }\end{array}$ \\
\hline $\begin{array}{l}\text { Amount of people } \\
\text { tested }\end{array}$ & 2150 & 308 & Not available & 450 & 308 & 125 & $\mathrm{~N} / \mathrm{A}$ \\
\hline $\begin{array}{l}\text { Deaths as of June } \\
\text { 8th }\end{array}$ & 3 & 0 & 1 & 15 & 0 & 0 & 6,016 \\
\hline
\end{tabular}

The local governments took action before local transmission of the virus was confirmed on the islands and the chosen measures can be considered adequate for the benefit of public health and also courageous as the entire economy would be shut down as a result. In contrast, during this same period soccer matches were still being played in Spain and Italy, and carnival was celebrated in the Netherlands despite news that the virus was present in Europe. This dilemma between public health measures and the economy was observed in most countries, followed by unprecedented repercussions. The islands were no exceptions in this as the restrictive measures, while effective, also led to much chagrin among the population, requiring repeated press conferences by the local governments to explain the need for these measures.

\section{SCARCITY IN HEALTHCARE EQUIPMENT AND PERSONNEL}

The overriding aim is to ensure that the local healthcare capacity is not overburdened and specifically that there are never more patients that require ventilatory support than there are suitable intensive care unit (ICU) beds.(9) On average for Europe, Asia and the U.S., the number of these beds are respectively $0.12,0.04$ and 0.28 per 1,000 people, with considerable variations even between regions with the same World Bank classification. Germany, for example, has 6.9 times more ICU beds than Portugal. $(10,11)$ In comparison, on Curaçao, Aruba, Bonaire, and St. Martin there are respectively $0.05,0.12,0.15$, and 0.073 beds per 1,000 people. The two smaller islands have no ICU.

While flattening the curve is the goal, many countries are also increasing their ICU capacity. While the islands can convert the respirators used in their operating rooms, they have no military or navy to provide additional ventilators and depend on external support to alleviate their scarcity of employees. The Dutch government has, however, prepared a navy ship with 30 ICU beds for the islands. Twelve ICU unit beds, including ventilators, personal protective equipment (PPE), and personnel arrived in St. Martin in March, whereas the other islands will receive aid later if needed.

The minister of Health of Curaçao announced that the Netherlands would be financing the wages of 102 medical personnel from the U.S. and Cuba if Curaçao financed their stay.(12)

The question is, how big of a burden will the disease be on the islands if left unmitigated? The Imperial College reports a strong correlation between the gross domestic product (GDP) per capita of a country and its population's underlying demography. (10) They argue that HICs tend to have a bigger proportion of the population who are above 65 years of age and therefore, have a higher incidence of severe disease and hospitalization. Although Aruba, Curaçao and St. Martin are officially classified as HIC, there is a big difference between their respective GDP per capita (16,778 USD, 17751 USD, and 22,047 USD) and, for example other HICs such as the Netherlands (53,024 USD) or Italy $(34,483$ USD).(13,14) Despite this gap, between 13 to $17 \%$ of the population on each of these islands is $>65$ years old, only slightly lower than the Netherlands (19\%) and Italy (23\%). (15-19)

Based on current data, older adults who have severe underlying medical conditions are at a higher risk for severe illness from COVID-19. $(20,21)$ The most recent census on Curaçao (2011) revealed that at least $27.4 \%$ of the residents have one or more chronic diseases and/or disorders.(22) According to the WHOSTEPwise Approach Survey (STEPS) conducted in Aruba, obesity, hypertension and diabetes were the most common diseases reported, affecting $77.1 \%, 40.7 \%$ and $5.4 \%$, respectively, of the population.(23) Non-communicable diseases (NCDs), 
TABLE 2. Overview of the impact of COVID-19 on all countries in the Caribbean region classified as a small independent developing state

\begin{tabular}{lcccc}
\multicolumn{1}{c}{ Country current as of June 8th } & Population $^{39}$ & $\begin{array}{c}\text { First reported } \\
\text { case COVID-1930 }\end{array}$ & $\begin{array}{c}\text { Current } \\
\text { confirmed cases }{ }^{30}\end{array}$ & Deaths ${ }^{30}$ \\
Anguilla & 18,090 & March 26th & 3 & 0 \\
Antigua and Barbuda & 98,179 & March 13th & 25 & 3 \\
Bahamas & 337,721 & March 15th & 101 & 11 \\
Barbados & 294,560 & March 17th & 92 & 7 \\
Belize & 399,598 & March 23rd & 18 & 2 \\
Bermuda & 71,750 & March 18th & 140 & 9 \\
British Virgin Islands & 37,381 & March 25th & 8 & 1 \\
Cayman Island & 61,944 & March 12th & 141 & 1 \\
Cuba & $11,059,062$ & February 24th & 2,045 & 83 \\
Dominica & 74,243 & March 22nd & 18 & 0 \\
Dominican Republic & $10,735,896$ & March 1st & 17,285 & 502 \\
Grenada & 113,094 & March 16th & 23 & 0 \\
Guadeloupe & 376,879 & March 13th & 162 & 14 \\
Guyana & 750,204 & March 11th & 127 & 11 \\
Haiti & $11,067,777$ & March 19th & 2,124 & 44 \\
Jamaica & $2,808,570$ & March 10th & 575 & 9 \\
Martinique & 358,749 & March 5th & 197 & 14 \\
Montserrat & 5,373 & March 18th & 11 & 0 \\
Puerto Rico & $3,189,068$ & March 13th & 3,776 & 136 \\
St. Barthelemy & 7,122 & March 1st & 6 & 0 \\
St. Kitts and Nevis & 52,441 & March 25th & 15 & 0 \\
St. Lucia & 181,889 & March 13th & 18 & 0 \\
St. Martin (French side) & March 1st & 41 & 3 \\
St. Vincent and the Grenadines & 36,824 & March 11th & 14 & 0 \\
Suriname & 101,390 & March 13th & $122^{40}$ & 240 \\
Trinidad and Tobago & 609,569 & March 12th & 117 & 8 \\
Turks and Caicos Islands & $1,208,789$ & March 23rd & 41 & 3 \\
U.S. Virgin Islands & 55,926 & 70 & 6 \\
\hline
\end{tabular}

primarily cardiovascular disease and cancer, are responsible for $79 \%$ of deaths in Curaçao and $85 \%$ in Aruba.(24) With both an aging population and a high incidence of NCDs, the islands are at a high risk of large impact from COVID-19.

\section{AN ECONOMIC DISASTER}

The economies of the islands are for a large part, if not solely, dependent on tourism. With the introduction of travel restrictions, tourism has come to a sudden stop. Emsley Tromp, former director of the Central Bank of Curaçao and St. Martin, estimates that the GDP of the islands may contract by 15 to $25 \%$. (25) The Minister of Finance, Economic Affairs, and Culture of Aruba, Ms. Xiomara Maduro, expects the GDP of the island to decline with $44,4 \%$. The stress scenario analysis of S\&P Global puts Aruba and Curaçao in respectively the $1^{\text {st }}$ and $11^{\text {th }}$ place of nations with the most affected GDP due to the loss of tourism as a result of the COVID-19-crisis.(26)

Furthermore, other sectors and industries that are dependent on the import of supplies have also been affected. The Curaçao business association (VBC) estimates that $45 \%$ of the population will lose their jobs, accounted for by the virtual stop of tourism-related industries.(27) To worsen matters, the majority of the islands were in a recession before the pandemic, with tourism being the only sector that was performing well. The island of St. Martin is still struggling with the recovery following Hurricane Irma in 2017, with the damages caused by the hurricane being in the billions of U.S. dollars. Following the hurricane, both the French and Dutch governments provided much needed financial aid to the island, yet the challenges the governments face for reconstruction are particularly difficult. Tahseen Sayed, the World Bank country director for the Caribbean, stated that because of the small size of the island (88 sq. $\mathrm{km}$ ), almost every citizen was directly impacted.(28) Similarly, Curaçao had been battling its own economic decline due to the closure of the local oil refinery, which led to an excessively high unemployment rate of $21 \%$.(29) With this pandemic, it faces a worsening of an already weak economy. SARS-CoV2 causing a massive global recession seems inevitable, and the six islands will be no exception.

\section{REGIONAL COMPARISON}

All six islands in the Dutch Kingdom are performing well compared to other similarly sized and populated islands in the Caribbean region. (Table 2) All islands in the region were spared the dramatic situation seen in countries such as China 
and Italy. None of them had to deal with ICU's reaching their maximum capacity, and many took extended measures to enforce social distancing. Most of the islands are now exploring the best ways to loosen the restrictions they imposed and reopen the economy safely.(30) Currently, a mandatory 14-day quarantine for incoming travelers has been implemented in many countries. With no active cases reported, Aruba and Anguilla are examples of islands that are now allowing non-essential businesses to reopen, although tourism has not yet been reinstated. In contrast, Antigua and Barbuda still have 25 confirmed cases and planned to reopen commercial flights in June, provided that incoming tourists have been tested negative to COVID-19 on arrival. For noncitizens, however, an entry will be denied if they have traveled to high-risk countries.(30) In Suriname, all airports and land borders have been closed, and the country is currently experiencing a second wave of positive cases following the recent presidential election. With a new President after 10 years, the country is expected to encounter daring challenges in fixing its downfallen economy. (40)

The Region of the Americas as a whole is now dealing with more than three million confirmed cases and has become the new epicenter for the disease. Amid this, authorities are starting preparations for hurricane season. Dr. Carissa Etienne, director of the Pan American Health Organization (PAHO) has called for unity between countries in facing the epidemic, and the Organization has donated 3.4 million testing kits to laboratories in the region.

\section{CHALLENGES AND RECOMIMENDATIONS FOR SIDS}

The United Nations officially introduced the term SIDS in 1992 as it became widely acknowledged that small island countries have their own peculiar vulnerabilities and characteristics. The difficulties they face in the pursuit of sustainable development are particularly severe and complex. (Table 3) Their growth and development are held back by high costs of communication, energy, and transportation. Furthermore, there is little to no opportunity to create economies of scale due to their small size, the disproportionately expensive public administration and infrastructure, and irregular international transport volumes.(31)

\section{Socio-economic measures}

From a socio-economic perspective, it is clear that down the line, the public health approach for mitigating the impact on (the amount and complications of) COVID-19 patients will surely not suffice. While suppression measures are maintained, vaccines and drugs are needed to influence the different phases of a global pandemic effectively. However, the Dutch Caribbean islands as SIDS have to date, demonstrated their ability to adequately and rapidly react and implement necessary safety measures for a pandemic. At the same time, the epidemic has again shed light on the daily healthcare challenges of the different islands. For example, if the ICUs are at maximum capacity, categorically excluding patients due to a shortage of ventilators may result in perceptions of unfairness within these societies. Therefore, hospitals and governments need to acknowledge this plausible threat and establish and implement policies that fairly allocate these scarce resources.(32) In preparation
TABLE 3. Difficulties facing small island developing states (SIDS) according to the Barbados Program Of Action adopted in 1994, further complemented by the Mauritius Strategy of Implementation of $\mathbf{2 0 0 5}$ and $\mathbf{M S I}+5$ Outcome document

\section{Small size}

Narrow range of resources, which forces undue specialization

Excessive dependence on international trade and hence vulnerability to global developments

High population density, which increases the pressure on already limited resources Overuse of resources and premature depletion

Relatively small watersheds and threatened supplies of fresh water

Costly public administration and infrastructure, including transportation and communication

Limited institutional capacities and domestic markets and limited export volumes, which are too small to achieve economies of scale

\section{Isolation}

Geographic dispersion and isolation from markets due to remote location High freight costs and reduced competitiveness leading to economic disadvantage

\section{Climate change and sea-level rise}

Short-term effects pose significant risks to the sustainable development Long-term effects may threaten the very existence and viability of some SIDS

\section{Natural and environmental disasters}

High vulnerability to natural and environmental disasters

Increasing impact of natural disasters with disproportionately high economy, social and environmental consequences

for future epidemics, closer cooperation between the Dutch Caribbean islands and arguably other Caribbean SIDS would be needed.

\section{External cooperation}

To date, Spain and Italy, while having the highest death rates in Europe, have received little to no help in the form of personnel or ventilators from the EU, and were late to start the discussions regarding the provision of financial aid.(33) One may, therefore, question if the islands can genuinely rely on outside help. The islands could benefit from their historical ties as previously constituting one country (the former Netherlands Antilles). In 2010, the union was formally dissolved, with Aruba already having exited in 1986. On a healthcare level, this has led to a unique situation where Aruba, Curaçao, and St. Martin as independent countries currently provide general healthcare services locally and refer patients abroad to either nearby countries (mostly Colombia) or The Netherlands for specialized care. Providing some of this specialized care locally divided over the islands has turned out to be unfeasible financially and logistically as some islands stand to benefit more than others.

A recent study has shown that the trends in life expectancy are more favorable in territories with less political autonomy such as Martinique, Guadeloupe, and the British Virgin Islands. However, this is not the case in territories with more political autonomy such as Puerto Rico, the US Virgin Islands, Aruba, and Curaçao.(34) The islands are too small to each develop and maintain an adequate, high-quality healthcare system for themselves. For a small population of up to 160,000 inhabitants for the largest island, there is insufficient demand for high-quality (tertiary) specialty care. Highly specialized care for such small numbers means higher health care expenses for the individual islands.(31) Closer cooperation 
and distributing care across the islands might, therefore, be a strategy to achieve stronger collaborations with Dutch (health) organizations. However, this is not without its challenges financially, logistically, and ethically. Depending on how care is distributed, some islands would face spending much more on healthcare. Logistically speaking, it would be a massive undertaking to fly-out patients regularly. It will also force several medical specialists to relocate and redesign their services if specific treatments are no longer feasible on their islands. Furthermore, separating people from friends and family in their most vulnerable moment, because a decision has been made to discontinue the provision of specific services on their islands would result in moral and ethical dilemmas. This delicate balance between public health and the economy requires a scientific and ethical platform supported by data and models for decision making.

\section{Provision of medical resources}

When we mirror the islands' current state of affairs on a larger scale, one may wonder what chance the smaller islands have in acquiring hospital equipment at a reasonable price. As various states and the federal government in the US are in a bidding war for ventilators and PPE (35), many have advocated that countries will need to become more self-reliant to prevent future healthcare crises, for example, not being reliant on foreign production of PPE. For islands with such small populations in the hundred thousand or less, a regional manufacturing agreement or large supply reservoir could be a more manageable objective.

Being individual municipalities of The Netherlands, the islands of Bonaire, Statia, and Saba can consistently expect help from the Dutch government directly. This is not the case for Aruba, Curaçao, and St. Martin, for which independently expanding their own ICU capacities would not be financially feasible. For The Netherlands, on the other hand, this epidemic was an unexpected added responsibility. The special municipalities are unable to treat the most seriously ill patients locally. They and thus the Netherlands have requested for these patients to be transferred to the larger independent islands. Due to their proximity to each other and the historical ties within the Kingdom, the Netherlands is luckily also providing (financial) aid to the other three islands. Nevertheless, this will not be infinite, and therefore, ties with other independent Caribbean States should also be explored.

\section{Workforce capacity}

Medical workforce capacity has long been an issue on the islands. They have long had to rely on a large part on foreign doctors, and most medical education cannot be followed on the islands themselves. Many students leave the islands for an education abroad, but only a few return.(36) Thus, a sizable number of indigenes from the islands are known to be working abroad (mostly in the Netherlands) in the healthcare industry. The dire healthcare needs on the islands resulting from this crisis highlight the importance of why the healthcare professionals from the various islands must unite and find ways in which their assistance can quickly be called upon when needed.

A good example to be less dependent on external help is an initiative by a group of young healthcare professionals from the various islands who, in 2017, formed an association to address this need. This association of medical professionals from the former Dutch Antilles (in the native language Asosiashon Mediko di Antias) is still in its early years but expanding quickly. As of now, with approximately two hundred members in its database, the association was able to recruit 65 professionals to offer local support for the islands' health care services during the current pandemic. The islands should develop and implement a framework for transportation, housing, financing, and quick hospital familiarization for foreign medical personnel in times of crisis. Thus, making it a less daunting step for foreign healthcare professionals.

\section{Communication measures}

Lack of clear communication on guidelines of care and the rise of fake news via social media increase levels of anxiety and stress, more so in groups with low levels of education who are not able to correctly interpret situation reports released by the government authorities or in groups within a non-medical field of expertise. Many biases play a huge role in interpreting the validity of the information. Cognitive bias explains how individuals create their own "subjective reality" from their perception of the input. This may dictate their behavior in the social world. The negativity bias is the phenomenon by which humans give greater psychological weight to bad experiences or news than good ones. Confirmation bias is a type of cognitive bias that involves favoring information that confirms your previously existing beliefs or biases. When such biases and fallacies are not adequately managed or corrected, it can lead to a crisis.

Risk communication should emerge long before a crisis occurs (preparedness), aiming to reduce the likelihood of a crisis event. However, there is a significant chance of miscommunication in risk communication. Recently a study has been started at the University of Utrecht and University of Groningen, The Netherlands, to assess the social impact of COVID-19 risk communication on vulnerable groups (older adults, ethnic minorities, and refugees) in the Kingdom of the Netherlands, including the Caribbean islands. This study will hopefully be used in guidelines for SIDS to inform better, prepare, manage, and cope with future pandemics.

\section{Financial (in)dependence}

Currently, the respective governments and central banks of Aruba and Curaçao have estimated that both islands would need somewhere between 750 and 900 million euros to accommodate and recover from this pandemic.(37) The Dutch government has decided to provide financial aid to the islands, which will allow the islands to provide some financial relief to citizens and businesses. The Dutch government, however, has put forth strict demands before the money can be given, such as a $12.5 \%$ salary cut for all civil servants, a salary cut of $25 \%$ for all ministers, and CEOs of government-owned companies can no longer earn more than 130\% of the Prime Minister's salary.(38) This financial dependence on the Netherlands has long been an issue within the Kingdom. The goal has always been temporary (financial) aid, which should ultimately lead to the islands' self-reliance. Despite the considerable political pressure from the Netherlands and many accompanying expert reports and plans, this goal is yet to be achieved. Further, due to the 
scale of SIDS, it is questionable if this can ever be achieved. To date, financial help from the Netherlands has been in the form of loans or development aid. Historically the Dutch financial aid to the islands has been low, around a yearly 500 USD per capita. In comparison, the French aid to their Caribbean territories is between 2,900-3,800 USD per capita, and the US spends around 2,500 USD and 1,000 USD per capita in Puerto Rico and the US Virgin Islands, respectively.(38)

A suggested solution is to structurally embed these extra costs in institutions such as is already done with the 'Waddenfonds' for the Frisian islands, a North Sea archipelago directly off the coast of the Netherlands.(38) This could be difficult due to the autonomous status of Curaçao, Aruba and St. Martin. Economic recovery following the pandemic will likely be slow as the local economies will only begin to recover when the economies in other countries have recovered, and traveling is restored to normal. Dutch aid will once again be needed, but a longer, more sustainable situation needs to be created in the future.

It is a fact that these six Caribbean islands will suffer significant consequences from the COVID-19 crisis both financially and medically. They are countries with economies driven by tourism and, therefore, long-term economic consequences will be catastrophic if not properly addressed. It is admirable and, at the same time, exemplary of the islands to not have allowed economic pressure to affect their public health decisions while trying to limit the medical consequences of this crisis. The Netherlands plays a vital role in providing both economic and medical assistance. The islands should, however, not forget to focus on cooperation with each other and adequately using their own native healthcare professionals living abroad. Every country is currently encountering its battles and will be facing very tough medical and ethical choices while attempting to manage the acute and chronic phases of this pandemic. However, as a global society, we should not neglect to draw attention to those countries that can bear the least.

Authors' contributions. PAM \& LJ conceptualized, wrote, critically appraised and approved the final version of the manuscript. AJD \& JB critically appraised and approved the final version of the paper.

\section{Conflicts of interest. None declared.}

Disclaimer. Authors hold sole responsibility for the views expressed in the manuscript, which may not necessarily reflect the opinion or policy of the RPSP/PAJPH and/or the Pan American Health Organization.

\section{REFERENCES}

1. Wilder-Smith A, Freedman D. Isolation, quarantine, social distancing and community containment: pivotal role for old-style public health measures in the novel coronavirus (2019-nCoV) outbreak. J Trav Med. 2020;27(2).

2. Barron L. Coronavirus Lessons From Singapore, Taiwan and Hong Kong [Internet]. Time Magazine. 2020 [cited 12 April 2020]. Available from: https://time.com/5802293/coronavirus-covid19singapore-hong-kong-taiwan/

3. Government of Sint Eustatius. Coronavirus updates (COVID-19) Sint Eustatius [Internet]. 2020. Available from: https:/ / www.facebook. com/euxgov/photos/a.1479300035499354/2988028264626516/ ?type $=3 \&$ theater

4. Rijksdienst Caribisch Nederland. Facts and figures on the coronavirus on Bonaire. [Internet]. 2020. Available from: https://www. facebook.com/rijksdienst.nederland/photos/a.1580504795496639/ $2588623011351474 /$ ?type $=3 \&$ theater

5. Public Entity Saba. COVID-19 update [Internet]. 2020. Available from: https://www.facebook.com/PublicEntitySaba/photos/a. $1240162112675317 / 3358464114178429 /$ ?type=3\&theater

6. Gobiernu di Korsou. Kosonan di Corona Vírùs na Kòrsou [Internet]. 2020. Available from: https://www.facebook.com/GobiernuKorsou/ photos/pb.129012707184616.-2207520000../3022436471175544/ ?type $=3 \&$ theater

7. Current Situation on Sint Maarten [Internet]. Sintmaartengov. org. 2020 [cited 4 June 2020]. Available from: http://www. sintmaartengov.org/government/VSA/Health-Updates/NOVELCORONAVIRUS/Pages/Current-Situation.aspx

8. Corona Updates Government of Aruba [Internet]. Gobierno de Aruba. 2020 [cited 4 June 2020]. Available from: https://www. arubacovid19.org/

9. Patrick GT Walker, Charles Whittaker, Oliver Watson et al. The Global Impact of COVID-19 and Strategies for Mitigation and Suppression. Imperial College London (2020). doi: https://doi. org $/ 10.25561 / 77735$

10. Rhodes A, Ferdinande P, Flaatten H, Guidet B, Metnitz P, Moreno R. The variability of critical care bed numbers in Europe. Intens Care Med. 2012;38(10):1647-53.
11. Phua J, Faruq M, Kulkarni A, Redjeki I, Detleuxay K, Mendsaikhan $\mathrm{N}$ et al. Critical Care Bed Capacity in Asian Countries and Regions. Crit Care Med. 2020;48(5):654-662.

12. Extra hulp uit VS en Cuba [Internet]. Antiliaans Dagblad. 2020 [cited 14 April 2020]. Available from: https://antilliaansdagblad. com/curacao/21320-extra-hulp-uit-vs-en-cuba

13. van Buiren K and Ernst L. Kerncijfers Caribisch Deel Koninkrijk. Amsterdam: Seo; 2019

14. World Bank 2020 Data. [online] Available at: https://data.worldbank.org/country/ [Accessed 13 April 2020].

15. Bevolking Caribisch Nederland in 2030 groter en grijzer [Internet]. Centraal Bureau voor de Statistiek. 2019 [cited 25 April 2020]. Available from: http://cbs.nl/nl-nl/nieuws/2019/31/bevolkingcaribisch-nederland-in-2030-groter-en-grijzer

16. Population Tables [Internet]. Centraal Bureau voor de Statistiek Curacao, 2019 [cited 25 April 2020]. Available from: https:/ / www.cbs. cw/website/population_3208/item/population-tables_1198.html

17. Quarterly Demographic Bulletin 2019 [Internet]. Centraal Bureau voor de Statistiek Aruba, 2019 [cited 25 April 2020]. Available from: http://cbs.aw/wp/index.php/2020/04/20/quarterly-demo graphic-bulletin-2019/

18. Resident population on 1st January [Internet]. Istituto Nazionale di Statistica. 2020 [cited 25 April 2020]. Available from: http://dati. istat.it $/$ Index.aspx?QueryId $=42869$ \&lang=en\#

19. CBS Statline [Internet]. Centraal Bureau voor de Statistiek Nederland. 2020 [cited 25 April 2020]. Available from: https://opendata. cbs.nl/statline/\#/CBS/nl/dataset/7461BEV/table?fromstatweb

20. Coronavirus Disease 2019 (COVID-19) [Internet]. Centers for Disease Control and Prevention. 2020 [cited 12 April 2020]. Available from: https://www.cdc.gov/coronavirus/2019-ncov/need-extraprecautions / people-at-higher-risk.html

21. Zhou F, Yu T, Du R, Fan G, Liu Y, Liu Z et al. Clinical course and risk factors for mortality of adult inpatients with COVID-19 in Wuhan, China: a retrospective cohort study. Lancet. 2020;395(10229):1054-62.

22. Centraal Bureau voor de Statistiek. Gezondheid en beperkingen in Curaçao [Internet]. Willemstad: 48-51; 2014 p. 48-51. Available from: https://www.cbs.cw/website/2011-census_3226/ 
item/gezondheid-en-beperkingen-in-curacao-publicatiereekscensus-2011_787.html

23. Pan American Health Organization. Health in the Americas, 2012 Edition. Summary: Regional Outlook and Country Profiles. Washington, D.C.: PAHO; 2012

24. Cho M, Marchand M, Vega E, Holder R, Luciani S, Constansia-Kook $\mathrm{J}$ et al. Health systems strengthening for noncommunicable disease control and healthy aging: integrated actions in Aruba and Curaçao. Rev Panam Salud Publica. 2019;43:e55.

25. Tromp E. The coronavirus and its economic fallout for the Monetary Union [Internet]. Curaçao Chronicle. 2020 [cited 12 April 2020]. Available from: https://www.curacaochronicle.com/post/opinion/ the-coronavirus-and-its-economic-fallout-for-the-monetary-union/

26. S\&P Global Ratings. Stress Scenario: The Sovereigns Most Vulnerable To A COVID-19-Related Slowdown In Tourism [Internet]. 2020. Available from: https://www.spglobal.com/ratings/en/research/ articles / 200317-stress-scenario-the-sovereigns-most-vulnerable-toa-covid-19-related-slowdown-in-tourism-11387024

27. Hendriksen K. Coronacrisis: Curaçaose ondernemers teleurgesteld in overheidshulp [Internet]. Caribisch Netwerk. 2020 [cited 12 April 2020]. Available from: https://caribischnetwerk.ntr. $\mathrm{nl} / 2020 / 03 / 25 /$ coronacrisis-curacaose-ondernemers-teleurgesteldin-overheidshulp/

28. Semple K. After a Caribbean Hurricane, the Battle Is Where, or Even Whether, to Rebuild [Internet]. Nytimes.com. 2020 [cited 4 June 2020]. Available from: https://www.nytimes.com/2019/10/07/ world/americas/hurricane-irma-saint-martin.html

29. Centraal Bureau voor de Statistiek Curacao. Het werkloosheidspercentage in april 2019 gestegen naar 21,2 procent [Internet]. 2019. Available from: https://www.cbs.cw/website/ press-releases-2019_3580/item/het-werkloosheidspercentage-inapril-2019-gestegen-naar-212-procent_2714.html

30. Charles J, Tavel J, Gamez Torres N. Latin America, Caribbean reopening economies. But COVID-19 still sharply rising. Miami Herald [Internet]. 2020 [cited 8 June 2020]. Available from: https:// www.miamiherald.com/news/nation-world/world/americas / haiti/article241249651.html

31. Croes M. Financiële relaties in het Koninkrijk. Na tien jaar: de reality check. [Internet]. Comité Koninkrijksrelaties.2015. [Cited 31 May 2020]. Available from: https:/ / www.comitekoninkrijksrelaties.org/ financiele-relaties-in-het-koninkrijk-na-tien-jaar-de-reality-check /

32. White DB, Lo B. A Framework for Rationing Ventilators and Critical Care Beds During the COVID-19 Pandemic. JAMA [Internet]. 2020 Mar 27; Available from: http://dx.doi.org/10.1001/jama.2020.5046

33. Elliott L. The coronavirus crisis has brought the EU's failings into sharp relief. [Internet]. the Guardian. 2020 [cited 12 April 2020].
Available from: http://www.theguardian.com/business/2020/ mar/29/the-coronavirus-crisis-has-brought-the-eus-failings-intosharp-relief

34. Verstraeten S.P.B. Population Health in the Dutch Caribbean: A comparative study of political context and health policy performance. [Internet]. Volksgezondheid Instituut Curaçao. [cited June 2 2020] Available from: https://vic.cw/storage/app/media/uploadedfiles/Dissertation\%20Soraya \%20final\%20version.pdf

35. Moné B. The federal government outbid states on critical coronavirus supplies after Trump told governors to get their own medical equipment [Internet]. Business Insider. 2020 [cited 12 April 2020]. Available from: https://www.businessinsider.com/ coronavirus-trump-outbid-states-on-medical-supplies-2020-3

36. Tong T, Getrouw Z, Jeung H, Holiday F. Artsentekort Antillen vereist structurele aanpak [Internet]. Medischcontact.nl. 2020 [cited 6 June 2020]. Available from: https://www.medischcontact.nl/nieuws/ laatste-nieuws/artikel/artsentekort-antillen-vereist-structureleaanpak.htm

37. Samson J. Financiële hulp aan Aruba, Curaçao, Sint-Maarten wordt geen gift [Internet]. Caribisch Netwerk. 2020 [Cited 12 April 2020]. Available from: https://caribischnetwerk.ntr.nl/2020/03/28/ financiele-hulp-aan-aruba-curacao-sint-maarten-wordt-geen-gift/

38. Samson J. Deadline voor miljoenenlening nadert: Regering SintMaarten wil eerst eigen parlement aanhoren. [Internet]. Caribisch Netwerk. 2020 [Cited 19 May 2020]. Available from: https:// caribischnetwerk.ntr.nl/2020/05/19/deadline-voor-miljoenenleningnadert-regering-sint-maarten-wil-eerst-eigen-parlement-aanhoren/

39. The World Factbook - Central Intelligence Agency [Internet]. Cia. gov. 2020 [cited 8 June 2020]. Available from: https:/ / www.cia.gov / library/publications/the-world-factbook/

40. COVID-19 We doen het Samen [Internet]. COVID-19. 2020 [cited 8 June 2020]. Available from: https: / / covid-19.sr/actueel/

42. UNCTADstat - Country profile [Internet]. UNCTADstat. 2020 [cited 11 June 2020]. Available from: http://unctadstat.unctad.org/countryprofile/en-GB/index.html

43. Villeret G. PopulationData.net [Internet]. PopulationData.net. 2020 [cited 11 June 2020]. Available from: https:/ / en.populationdata.net/

Manuscript received on 29 April 2020. Revised version accepted for publication on 18 June 2020

\section{El brote de SARS-CoV-2 en las islas del Caribe del Reino de los Países Bajos: un desafío singular}

RESUMEN A medida que avanza la pandemia de síndrome respiratorio agudo severo por coronavirus 2 (SARS-CoV-2), los países dependen unos de otros para adquirir conocimientos sobre las medidas eficaces para contener el virus. Las medidas de salud pública dirigidas a suprimir la transmisión han demostrado su eficacia en Singapur, Hong Kong y Taiwán. La aplicación y la adhesión a esas intervenciones representa un desafío, ya que los gobiernos necesitan encontrar un equilibrio entre las estrategias de mitigación y supresión necesarias y la interrupción de las actividades socioeconómicas. Al tiempo que los países grandes y de altos ingresos luchan por mantener sus sistemas de salud y sus economías en funcionamiento, los pequeños estados insulares en desarrollo se enfrentan a retos aún más importantes. Muchas islas del Caribe, incluidas las seis islas del Reino de los Países Bajos, han aplicado medidas de salud pública estrictas de manera rápida, pero se enfrentan a desafíos singulares.

Palabras clave Coronavirus; pandemias; Indias Occidentales; Región del Caribe; Américas. 